\title{
NONNOEOPLASTIC FINDINGS OF THE URINARY BLADDER IN CATTLE AND WATER BUFFALO IN THE BLACK SEA REGION OF TURKEY*
}

Yllmaz Aydın**

I. Ayhan $\ddot{z}_{z u l}$ ***

\begin{abstract}
Türkiye'nin Karadeniz bölgesindeki sığır ve mandaların sidik keselerinde saptanan nonneoplastik bulgular
\end{abstract}

Summary: Nonneoplastic findings observed in urinary bladders of 131 adult cattle and water buffaloes slaughtered in abattoirs in the Black Sea region of Turkey were studied histologically. Although their macroscopical appearance showed tumourous, they were not found to be tumours microscopically. They contained various types of nonneoplastic findings. It was prominent that these different types of lesions were generally found together. The most frequent form encountered were simple, nodular or papillary types of hyperplasia as average $59 \%$. It was followed by focal or diffuse haemorrhagia (43\%), oedema (39\%) and aggregations of lymphoid cells (20\%) in the propria mucosa. The incidence of inflammatory lesions was 39\% in average.

Özet: Türkiye'de Karadeniz bölgesi mezbahalarında kesilen iki yassın üzerindeki sı̆̆ır ve mandalara ait 131 adet sidik kesesi örneğinde saptanan nonneoplastik bulgular histopatolojik olarak incelendi. Makroskobik görünüşleri tümörü andıran bu sidik kesesi örneklerinin mikroskobik olarak tümör olmadı $\breve{g} l$, buna karşıllk değişik tiplerde nonneoplastik bulgular içerdiği saptandı. Örneklerin çŏ̆unda farklı lezyonların birarada bulunması dikkat çekiciydi. Transisyonel epitelin hiperplazisi, \%59'luk oranila en sik karsılaşılan formdu. Bunu lamina propriadaki fokal veya diffuz kanamalar (\%43), ödem (\%39) ve lenfoid hücre infiltrasyonlart $(\% 20)$ izliyordu. Yangısel lezyonların orant $\% 39^{\prime} d u$.

\section{Introduction}

Nonneoplastic findings beside tumours in urinary bladders were reported from various animals and humans by several researchers (1, $3,4,7,11,13)$. They pointed out the importance of the nonneoplastic formations in better understanding the pathology of tumours of the urinary bladder. Nonneoplastic forms believed to happen as reactions to chronic irritations, infalamation and existed in transitional epithelium in forms of hyperplasia, metaplasia and as proliferation in the mucosa $(1,2,7,11,13)$. These types of malformations in cattle are generally caused by bracken fern (Pteridium aquilinum). The effect of this plant causing nonneoplastic and neoplastic formations in the urinary bladder was precisely demonstrated $(4-6,8,12)$.

The objective of this study was to determi- ne histologically various nonneoplastic lesions which were reported to be caused by bracken fern and lead to tumours in cattle and water buffalo in the Black Sea region of Turkey.

\section{Materials and Methods}

Fourteen provinces of the Black Sea region of Turkey where enzootic haematuria occurs among cattle were included in this study. The urinary bladders from 5567 cattle over two years slaughtered between 1991 and 1993 were examined macroscopically. Neoplastic or suspect samples separated from those of normal appearance were preserved in $10 \%$ neutral formalin in 30-40 liter jars and transfered to the Department of Pathology, Faculty of Veterinary Medicine, University of Ankara for histopathological examination. Of 5567 samples, 946 were so assessed.

\footnotetext{
* This study was supported by Research Fund of the University of Ankara (Project No: 90-10-00-03).

* Dr, Department of Pathology, Faculty of Vetcrinary Medicine, University of Ankara, 061 10, Ankara. Turkey.

*** Prof. Dr. Deparment of Pathology. Faculty of Veterinary Medicine, University of Ankara, 061 10, Ankara, Turkey.
} 


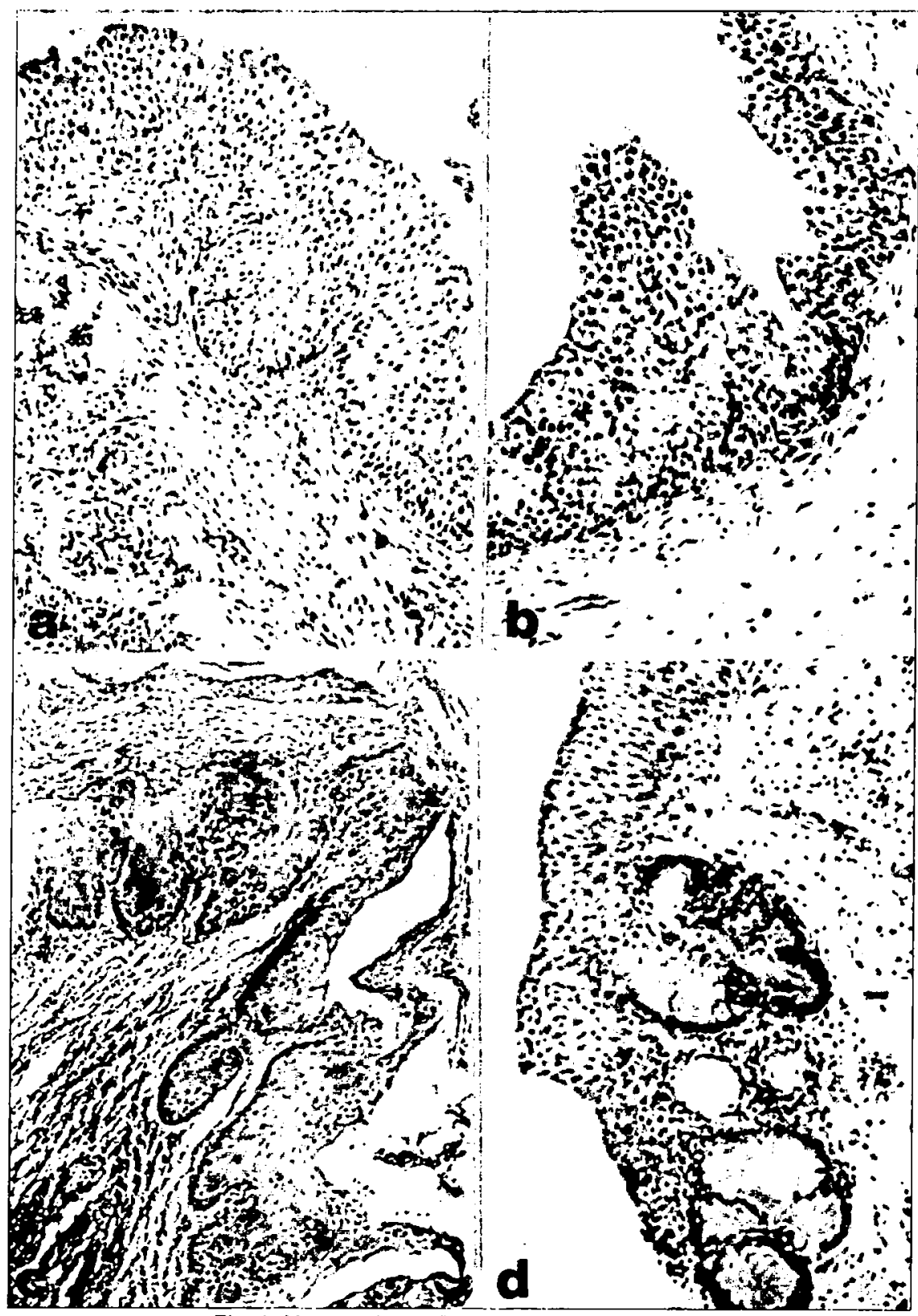

Fig. I. Nonneoplastic tindings in urinary bladders.

a) Nodular hyperplasia with chronic cystitis, H.E. x250.

b) Papillary hyperplasia projected into the lumen. H.E. $x 100$.

c) Keratinizing squamous metaplasia and chronic inflammatory infiltration of the urinary bladder. H.E. x 125. d) Cystitis glandularis with formation of mucin-producing glands.

Notice the abrupt variation from transitional to columnar epithelium. H.E. x100.

Portions of lesions taken from all of the samples were processed through alcohols and xylene, embedded in paraffin, sectioned at 5-10 $\cdot \mathrm{m}$, and stained with haematoxylin and eosin.

As a result of histological examination, 131 specimens (127 cattle and 4 buffaloes) were found not to be tumourous, and they were included in this study.

\section{Results}

Macroscopically, location of nonneoplastic formations in 131 urinary bladders varied greatly. In some specimens the lesions occupied a single area. In others nonneoplastic growths occurred in more than one area of the bladder. Totally, in 107 (average 82\%) specimens, the lesions occurred on the ventral and lateral walls which were in constant contact with urine, in 12 (average $9 \%$ ) in the neck and in 3 (average 2\%) at the vertex. In 9 (average $7 \%$ ) specimens the lesions occupied over the entire bladder.

Histopathological changes in the urinary 
Table 1. Nonneoplastic findings detected in a total of 131 cattle and water buffaloes urinary bladders.

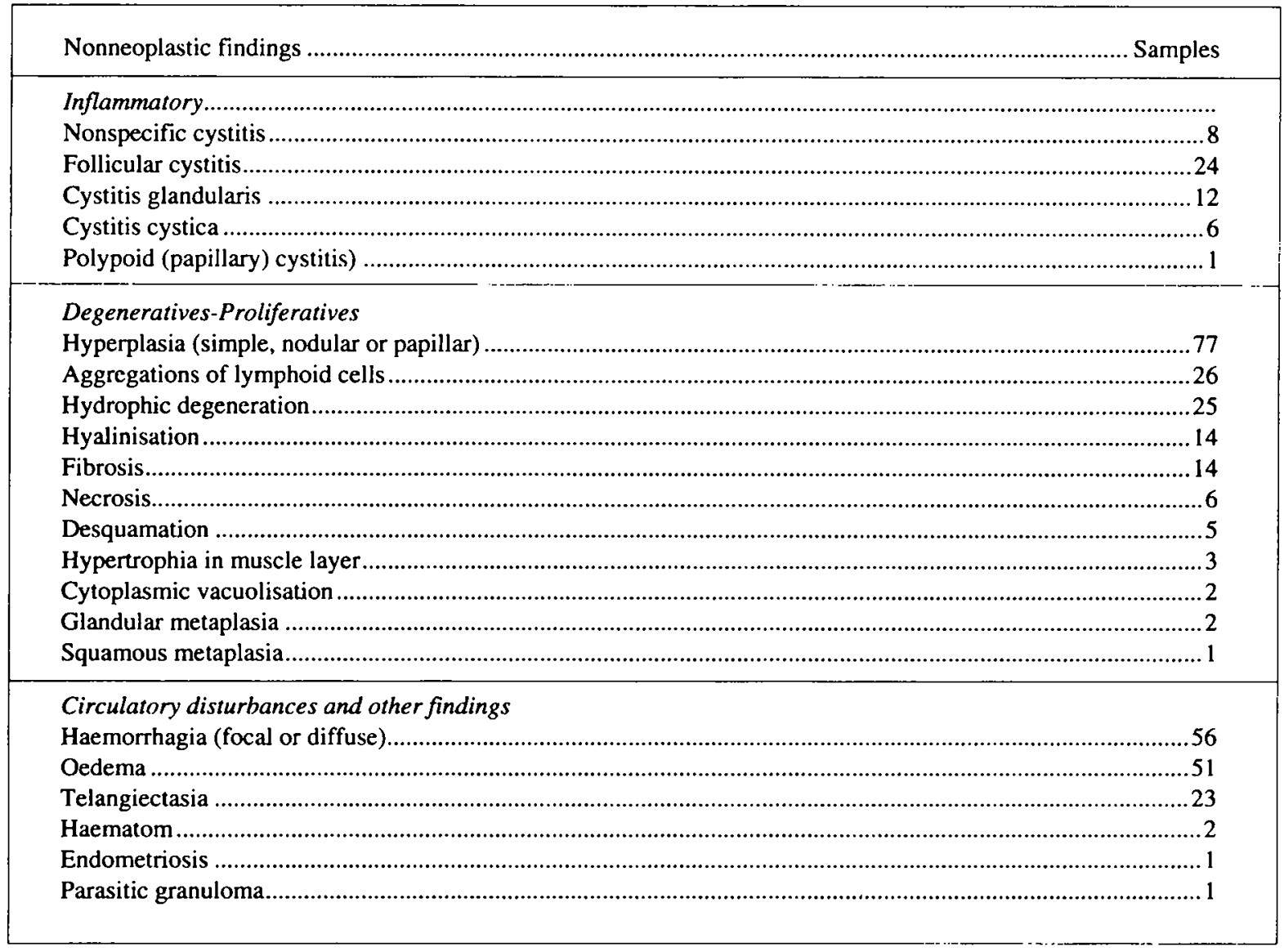

bladders might be classified as inflammatory, degenerative-proliferative, circulatory and other findings (Table 1). The incidence of inflammatory lesions was $39 \%$ in average. Hyperplasia of the transitional epithelium was the most frequent form encountered as 59\% in average, which might be simple, nodular, or papillary type, and associated with the most of other nonneoplastic changes. Nodular hyperplasia consisted of nodular downgrowths which extend into the lamina propria of urinary bladder (Fig. 1a). Papillary hyperplasia was differed from simple hyperplasia in that the surface was papillary rather than even and was projected into the lumen (Fig. 1b). Squamous metaplasia was seen as the replacement of transitional cell epithelium by squamous cells with keratinization (Fig. 1c). In cystitis glandularis the folds had numerous areas where slightly thickened epithelium extended into the lamina propria. In some crypts, the epithelium had undergone metaplasia to columnar cells, and sometimes there were gobletshaped (Fig. 1d).

In circulatory disturbances, haemorrhagia, oedema, and telangiectasia occurred in the most of specimens. In some specimens aggregations of lymphoid cells, fibrosis, hyalinization were also present in the lamina propria. In a few specimens, cytoplasmic vacuolization, desquamation, metaplasia in transitional epithelium; necrosis, endometriosis, parasitic granuloma in the propria mucosa, and hypertrophia in muscle layer were associated with above findings.

\section{Discussion}

This study has established the number and types with histopathological appearances of nonneoplastic findings in 131 urinary bladders from cattle and water buffaloes in the Black Sea region of Turkey. Although the exact nature of the aetiologic agents causing this nonneoplastic lesions in urinary bladders is unknown, it is reasonable to presume that the most of nonneoplastic findings in urinary bladder of cattle in this region were causally related to bracken fern. Since we observed that bracken fern was always present on farms along the Black Sea region and that the animals were always exposed to it. The role of bracken fern in the aetiology of enzootic haematuria and also urinary bladder tumours appears certain, because of the strong geographical association. This close association between bracken fern infested farms and enzootic haematuria with various nonneoplastic lesi- 
ons and tumours has also been clearly demonstrated $(5,6,8-10,12)$. We think that urinary bladder tumours had been brought about by these nonneoplastic lesions bound to the effect of bracken fern. Because small amounts of this plant given continuously to the cattle resulted in first nonneoplastic and later neoplastic formations in urinary bladders $(8,12)$.

In this study various inflammatory, degenerative-proliferative, circulatory changes were found. Similar changes have been reported with characteristic histological appearances by several investigators $(1,3,7,11,13)$. They were considered the possible precancerous role of several nonneoplastic changes. In the present study histologic similarities also suggest that urinary bladder tumours may be arise from alteration of the urinary bladder mucosa such as hyperplasia, metaplasia, or other growths.

In conclusion, epidemiologic studies are important in cancer research, since the recognition of differences in the frequency of particular lesions or tumours between population groups in different regions has often led to the identification of specific aetiological factors. In this study we observed that 131 specimens were contained various nonneoplastic findings, except for tumourous ones. The occurrence of this lesions lead to tumours are rare in cattle living outside areas of endemicity and relatively infrequent when bracken fern is not present. Thus, bracken fern may be criminated as responsible to the most of this lesions.

\section{Acknowledgement}

We are grateful to the staff of abattoirs in the Black Sea region of Turkey, for providing the material of this study.

\section{Kaynaklar}

1. Brobst, D.F. and Olson, C. (1963). Neoplastic and proliferative lesions of the bovine urinary blader. Amer J Vet Res, 24: 105-110.

2. Friedell, G.H., Jacobs, J.B., Nagy, G.K. and Cohen, S.M. (1977). The pathogenesis of bladder cancer. Amer J Pathol, 89: 431-442.

3. Frith, G.H. (1979). Morphologic classification of inflammatory, nonspecific, and proliferative lesions of the urinary bladder of mice. Invest Urol, 108: 565-567.

4. Göksoy, K. (1966). Stğır mesane tümörlerinin teşekkülünde egrelti otu (Pteris aquilina)'nun rolï. $\mathrm{PhD}$ Thesis, Ankara.

5. Hopkins, N.C.G. (1986). Aetiology of enzootic haematuria. Vet Rec, 118: 715-717.

6. McKenzie, R.A. (1978). Bovine enzootic haematuria in Queensland. Aust Vet J, 54: 61-64.

7. Mostofi, F.K. (1954). Potentialities of bladder epithelium. J Urol, 71: 705-714.

8. Pamukçu, A.M., Göksoy, S.K. and Price, J.M. (1967). Urinary bladder neoplasms induced by feeding Bracken fern (Pteris aquilina) to cows. Cancer Res, 27: 917 924.

9. Pamukçu, A.M. (1974). Tumours of the urinary bladder In: Bulletin of the World Health Organization, Geneva, Switzerland.

10. Pamukçu, A.M. (1983). Tumors of the urinary bladder in domesticated animals. In: The pathology of bladder cancer. Eds. G.T. Bryan and S.M. Cohen, Vol.I, CRS Press, Boca Raton, Florida.

11. Roe, F.J.C. (1964). An illustrated classification of the proliferative and neoplastic changes in bladder epithelium in response to prolonged irritation. $\mathrm{Br} \mathrm{J}$ Urol, 36: 238-253.

12. Rosensenberger, G. und Heeschen, W. (1960). Adlerfarn (Pteris aquilina)-die ursache des sog. Stallrotes der Rinder (Haematuria vesicalis bovis chronica). Deutschoester Tieraerztl Wchnschr, 67: 201-208.

13. Wiener, D.P., Koss, L.G., Sablay, B. and Freed, S.Z. (1979). The prevalance and significance of Brunn's nests. cystitis cystica and squamous metaplasia in normal bladders. J Urol, 122: 317-321. 